\title{
A desintegração do tempocentrismo como contemplação estética: as reminiscências de Claude Lévi-Strauss sob os Tristes Trópicos
}

\author{
Cornelia Eckert e Ana Luiza Carvalho da Rocha \\ Programa de Pós Graduação em Antropologia Social, IFCH, UFRGS. \\ «O eu não é apenas odioso: não tem lugar entre um nós e um nada» \\ (C. Lévi-Strauss, Tristes Trópicos).
}

Há uma famosa frase na obra escrita por Claude Lévi-Strauss em 1955, Tristes Tropiques (Tristes Trópicos) ${ }^{1}$ que ressaltamos aqui, logo na introdução deste artigo, como forma de guiar uma reflexão sobre as diversas camadas da contemplação estética que realizou, em particular, o pensamento levistraussiano quando confrontado, em sua gestação, com a Diferença, momento especial em que acreditamos ser possível pensar os primeiros passos do que viria a ser, posteriormente, denominado de Estruturalismo.

Trata-se de um momento sui generis de uma antropoética levistraussiana onde o autor comenta, face às marcas do tempo agitado que rege a vida nas cidades brasileiras dos anos 1930: "Certas cidades da Europa adormecem suavemente na morte; as do Novo Mundo vivem febrilmente uma doença crônica; eternamente jovens, jamais são saudáveis, porém"².

Certamente, em Tristes Trópicos, C. Lévi Strauss nos ensina autrement o estruturalismo por meio de uma rara descrição de sua experiência de campo no Brasil, onde o exercício de ordenação temporal múltipla, plural e complexa de suas reminiscências torna-se, finalmente, a forma perfeita para revelar a densidade existencial dessa viagem como parte de sua iniciação antropológica.

Desafiado pela paisagem de formas informes que configuram as cidades do Brasil, o pensamento levistraussiano revela o processo de negociação entre formas diversas de construir-se etnólogo, ora hedonista, ora cerebral. Sem dúvida, sabemos que será, posteriormente, em suas obras clássicas, no reino da racionalidade, que esse autor apontará os elementos da dualidade, da oposição e da polaridade anunciados, décadas passadas, por antropólogos franceses como Robert Hertz e Marcel Mauss.

Entretanto, em Tristes Trópicos, já se anuncia o Lévi-Strauss cerebral dos

\footnotetext{
${ }^{1}$ LEVI-STRAUSS, Claude. Tristes Tropiques. Paris, Plon 1955.

${ }^{2}$ LEVI-STRAUSS, Claude. Tristes Trópicos, São Paulo, Cia das Letras, 1998, p.92
} 
comentários introdutórios à obra de Marcel Mauss. Segundo Jacques Meunier ${ }^{3}$ entre o poeta e o cientista social, a narrativa levistraussiana dos Tristes Trópicos penderá antes para a visão de um engenheiro do social do que para o testemunho dionisíaco de um mero explorador de novos mundos. Essa falta de espontaneidade será justificada por uma concentração teórica e metodológica do autor, que resultará na fundação dos postulados do estruturalismo lévistraussiano. A contemplação estética do antropólogo em Tristes Trópicos anuncia, déjà, algumas de suas obras futuras, o Pensamento Selvagem $^{4}$ e As Mitológicas ${ }^{5}$.

Clifford Geertz considera que não há obra mais auto-referencial que esta. De fato, Tristes Trópicos é um ensaio subjetivo, em que o antropólogo se entrega a uma etnologia reveladora do eu, estilo de narrativa etnográfica que contrasta fortemente com as demais obras de C. Lévi-Strauss onde prepondera seu olhar científico face às instituições culturais em seu estado quase puro, o tão citado kantianismo sem sujeito transcendental, como o denominou Paul Ricoeur ${ }^{6}$.

A atitude de aventura intelectual que preside a viagem ordinária entre os labirintos das cidades brasileiras, na América tropical, contraposta aos constrangimentos do olhar científico, será encontrada no diário de viagem de Lévi-Strauss em seus comentários sobre a cidade de São Paulo: Ao invés desses turistas europeus que ficam amuados por não poderem aumentar as suas panóplias de caçadores mais uma catedral do século XIII, alegra-me ter de me adaptar a um sistema sem dimensão temporal, para interpretar uma forma diferente de civilização. Mas caio no erro oposto: uma vez que essas cidades são jovens, e extraem dessa juventude a sua essência e justificação, tenho dificuldade em perdoar-lhes o facto de não continuarem a sê-lo ${ }^{7}$.

O certo é que essa obra transcende aos próprios objetivos do autor, uma vez que, em sua narrativa sobre os Trópicos, Lévi Strauss nos permite compreender a ambigüidade de um pensamento que, ao elogiar simultaneamente a ordem da razão e a

\footnotetext{
3 A propósito ver artigo de Jacques MEUNIER “Tropicales”, In: Magazine Litttéraires. Numero 223, DOSSIER Paris octobre 1985, p 40.

${ }^{4}$ La pensée sauvage. Paris, Plon, 1962. Em português O pensamento selvagem. São Paulo, Companhia Editora Nacional, Editora da Universidade de São Paulo, 1970.

${ }^{5}$ Mythologiques I, Le cru et le cuit, Paris, Plon, 1964. Mythologiques II, Du miel aux cendres, Paris, Plon, 1966, Mythologiques III, L’origine des manières de table. Paris, Plon, 1968, Mythologiques IV, L'homme nu. Paris, Plon, 1971.

6 RICOEUR, Paul apud ECKERT, Cornelia e ROCHA, Ana Luiza Carvalho da. "A interioridade da experiência temporal do antropólogo como condição da produção etnográfica”. In: Revista de Antropologia. Volume 41, número 2, 1998. São Paulo, Faculdade de Filosofia, Letras e Ciências Humanas, Universidade de São Paulo. P. 107 à 135.

${ }^{7}$ LEVI-STRAUSS, Claude. Tristes Trópicos. Lisboa, Edições 70, 1981.p. 89.
} 
ordem da natureza, busca no trajeto científico a aproximação com essa última. Em uma obra posterior a Tristes Trópicos - Le regard éloigné (O Olhar Distanciado $)^{8}$ - esse tema será retomado de forma mais sofisticada quando, então, o autor desenvolve a idéia de que o pensamento cientifico, ao mesmo tempo que alimenta uma reflexão sobre o mundo das coisas, ampliando os horizontes do conhecimento humano, revela-se como insignificante face a própria grandeza da vida humana.

Neste sentido, os comentários de Lévi-Strauss sobre a "cidade síntese do Brasil meridional", Araponga, no Estado do Paraná, em 1938, é exemplar: Talvez mais preciosa, a cidade se situa na confluência da natureza e do artifício. Congregação de animais que encerram dentro de seus limites sua história biológica e que ao mesmo tempo a modelam com todas as suas intenções de seres pensantes, por sua gênese e por sua forma a cidade depende simultaneamente da procriação biológica, da evolução orgânica e da criação estética. É a um só tempo objeto da natureza e sujeito da cultura; indivíduo e grupo; vivida e sonhada; a coisa humana por excelência9.

Em Tristes Trópicos prepondera um tom bucólico e nostálgico na descrição da paisagem humana e natural das cidades brasileiras, divulgando, em best seller, um país cuja civilização urbana encontra-se ameaçada pela devastação do Tempo, assim como, território natural e artificial, fruto da procriação biológica e da criação estética de seus habitantes. Sim, são tristes os Trópicos porque neles a vida humana, submetida à flecha do tempo, encontra-se degradada.

Comparando-se os relatos sobre o sertão do Brasil e as cidades situadas na costa litorânea, a narrativa biográfica e etnográfica de Lévi-Strauss se abre a contradições. Os Trópicos despontam, a um só tempo, tristes e exuberantes. Reconhece, o autor de Anthropologie Structurale (Antropologia Estrutural) ${ }^{10}$ que sob os Trópicos o tempo se enrola e desdobra-se sobre si mesmo, ora percorrendo o ritmo violento e agitado das grandes transformações urbanas em sua luta para domesticar a paisagem natural, fazendo-a dobrar-se à ação humana no tempo, ora aderindo ao ritmo calmo e lento, desfiando o mito europeu do Progresso, evocando as formas de vida dos Caduveo, dos Bororo, dos Nambiquara e dos Tupi-Guarani, dos seus estilos e de suas linguagens que preponderam nas regiões mais longínquas da costa brasileira.

Face ao ritmo da agitação temporal da civilização sob os Trópicos, em sua prosa

\footnotetext{
${ }^{8}$ LEVI-STRAUSS, Claude. Le regard éloigné. Paris, Plon, 1983.

${ }^{9}$ LEVI-STRAUSS, Claude. Tristes Trópicos, São Paulo, Cia das Letras, 1998, p.116.

${ }^{10}$ LEVI-STRAUSS, Claude. Anthropologie structurale. Paris, Plon, 1958.
} 
poética Lévi-Strauss constata, ao referir-se à fundação da cidade de Goiânia, que o ritmotemporal vivido nesta região do planeta não tem uma continuidade histórica e nem diacronia, uma vez que sua paisagem não dura no tempo (e espaço). Evocando a figura de "Cadmo, o civilizador", que ali "semeara os dentes do dragão", em suas palavras: numa terra esfolada e queimada pelo sopro do monstro, esperava-se ver os homens crescerem $^{11}$.

Adentrando a região do Pantanal, diante do espetáculo exuberante da natureza e de seus povos, a contemplação estética do etnólogo avoluma-se em melancolia, na contraposição entre os "trópicos ermos" e os "trópicos lotados", ou o "equilíbrio superficial entre culturas primitivas e a experiência efêmera da civilização sob os Trópicos; seu pensamento europeu projeta o futuro dos acontecimentos na Europa da II Grande Guerra: Com a América indígena, acalento o reflexo, fugaz mesmo ali, de uma era em que a espécie se encontrava na escala de seu universo e em que persistia uma relação adequada entre o exercício da liberdade e seus sinais ${ }^{12}$.

Nessa obra, que apenas em parte nos remete ao Brasil, Lévi-Strauss sobrepõe, em suas anotações de viagem, suas reminiscências pessoais eurocêntricas, as que compartilha com o Velho Continente.

De fato, à contemplação estética do Novo Mundo interpõe-se o relato biográfico de Lévi-Strauss e de suas experiências de viagens no mundo, narradas num estilo bricoleur da memória fragmentada sob a égide do tempo agitado. Mais do que isto, pode-se sugerir que Tristes Trópicos é, entre todos os seus escritos produzidos, o único com um estilo mais informal e, em cuja narrativa etnográfica, reconhece a presença do si-mesmo no encontro com outro.

A descrição etnográfica das descontinuidades das estruturas espaço-temporais da vida urbana sob os Trópicos (eternamente jovens, jamais são saudáveis, porém), esboça o postulado universalista que marcará o conjunto de sua obra: Afinal, um branco podia ser tão - somente um homem. É no trajeto desse espanto reflexivo ${ }^{13}$, marcado pelo encontro etnográfico entre o Velho Mundo e os Trópicos, que se pode ver o estruturalismo levistraussiano em formação, ou seja, Brasil central e Ásia do sul, dois casos, objetos definidos por suas formas, suas cores, suas estruturas particulares, que

\footnotetext{
${ }^{11}$ LEVI-STRAUSS, Claude. Tristes Trópicos, São Paulo, Cia das Letras, 1998,. p.118.

12 LEVI-STRAUSS, Claude. Tristes Trópicos, São Paulo, Cia das Letras, 1998, p.140.

13 CANEVACCI, Massimo. "São Paulo e Nova York 'dentro' de Lévi-Strauss. In: A cidade polifônica. Studio Nobel. p. 78.
} 
Ihe conferem uma existência independente dos seres vivos que os ocupam ${ }^{14}$.

À medida que adentra as diferentes regiões do Brasil, do litoral ao sertão, LéviStrauss revisita em "seu tapete voador" as suas lembranças européias, isto porque, nessa obra, que apenas em parte nos remete ao Brasil, Lévi-Strauss, sobrepõe, em suas anotações de viagem, suas reminiscências pessoais eurocêntricas, as que compartilha com o Velho Continente. Vai-se da Ásia do Sul à América do Sul, numa espiral de associações díspares de imagens-vestígios (a Europa faustiana, a Ásia miserável e superpovoada, o pulular microbiano da América) contra as quais luta insistentemente na tentativa de enquadrá-las pela via de um pensamento que se aventura nos meandros da coisa pensada.

Neste traveling mental, o narrador é conduzido do Brasil central à Ásia do Sul, lá onde de início "enxergava coisa, aqui noto apenas criaturas", de tal forma interpõe-se a "densidade humana entre o observador e um objeto que se dissolve" que, ao fundador da antropologia estrutural, cabe reconhecer: "É preciso a experiência para senti-las" ${ }^{15}$, uma vez que é a experiência que, "de chofre, restitui uma dimensão fundamental da vida humana" sob os Trópicos. Trata-se aí de reconhecer, na oposição entre as "cidades mumificadas do Velho Mundo" e as "cidades fetais do Novo", que "o que chamamos exotismo traduz uma desigualdade de ritmo, significativa durante alguns séculos, e encobrindo um destino que poderia ser igual..." 16.

Acordando-se à idéia de que é necessário "muita alma" para compreender a polarização entre luxo e miséria nas Londrinas, Rolândias e Arapongas das regiões interioranas do Brasil, onde a vida urbana oferece tamanho contraste, cravando suas raízes no coração da floresta, o etnólogo reconhece, que a cidade sob os Trópicos pode ser comparada a uma sinfonia ou a um poema; são objetos da mesma natureza. Entretanto, seu pensamento euclidiano reconhece que diante do insidioso espetáculo de caos e desordem que há sob os Trópicos, a evolução animal se cumpre segundo fases mais lentas que as da vida urbana; se hoje eu contemplasse o mesmo local, talvez verificase que o híbrido rebanho desapareceu: pisoteado por uma raça mais vigorosa e mais homogênea de arranha-céus implantados nessas margens que uma auto-estrada fossilizou com asfalto ${ }^{17}$.

$\mathrm{Na}$ perspectiva da poética narrativa levistraussiana quase se pode afirmar que o

\footnotetext{
${ }^{14}$ LEVI-STRAUSS, Claude. Tristes Trópicos, São Paulo, Cia das Letras, 1998, p.134.

${ }^{15}$ LEVI-STRAUSS, Claude. Tristes Trópicos, São Paulo, Cia das Letras, 1998, p.135.

${ }^{16}$ LEVI-STRAUSS, Claude. Tristes Trópicos, São Paulo, Cia das Letras, 1998, p.147.

${ }^{17}$ LEVI-STRAUSS, Claude. Tristes Trópicos, São Paulo, Cia das Letras, 1998, p.195.
} 
autor desta frase reconhece que, aos olhos do europeu, a cidade sob os Trópicos torna-se um verdadeiro objeto temporal, ...um sistema sem dimensão temporal, para interpretar uma forma diferente de civilização ${ }^{18}$. Trata-se, pois de compreender muito mais do que explicar as ações rítmicas das quais é resultante a paisagem humanizada tropical, onde o pluralismo de solicitações temporais jamais deixou instaurar, como no Velho Mundo, a intimidade milenar entre o homem e o solo, na linha do que um espírito malicioso já havia definido a América: uma terra que passou da barbárie à decadência, sem conhecer a civilização ${ }^{19}$.

Pode parecer estranho querer privilegiar a noção da reminiscência e da interpretação na obra deste intelectualista da supremacia sincrônica, autor de Les Structures Elémentaires de la Parenté (das Estruturas Elementares do Parentesco) ${ }^{20}$. No entanto, como lembrar aqui as reflexões de Lévi-Strauss em torno da Natureza e da Cultura quando esse autor, através da alquimia de palavras, pensamentos e lembranças, em seu "trópicos do sonho", afirma para as complexas relações que reúnem determinadas formas de vida humana certas paisagens que é preciso ter viajado pela América para saber que essa harmonia sublime, longe de ser uma expressão espontânea da natureza, provém de acordos longamente buscados durante uma colaboração entre o local e o homem ${ }^{21}$.

Cidades e sítios naturais em Bengala ou em Goiás, territórios cuja desintegração da relação entre homem e cosmos é levada ao extremo limite, aos olhos do europeu, traduzem-se como a densidade humana largada dentro de um nada, gerado pela história, jogados de um lado para o outro pelas motivações mais elementares do medo, do sofrimento e da fome $e^{22}$.

Segundo esse autor, o europeu que vive na América tropical enfrenta problemas... as próprias modalidades da vida humana oferecem-lhe incessantemente temas de reflexão ${ }^{23}$ assim como o viajante europeu que fica desconcertado com essa paisagem que não se enquadra em nenhuma de suas categorias tradicionais $^{24}$. Mais tarde, em seu tapete de preces, evadindo da América tropical para regiões da Ásia meridional, comenta sobre o povo trágico que nela habita:

\footnotetext{
${ }_{18}^{18}$ LEVI-STRAUSS, Claude. Tristes Trópicos, São Paulo, Cia das Letras, 1998, p.91.

${ }^{19}$ LEVI-STRAUSS, Claude. Tristes Trópicos, São Paulo, Cia das Letras, 1998, p.91.

${ }^{20}$ LEVI-STRAUSS, Claude. Les Structures Elémentaires de la Parenté. Paris, PUF, 1949.

${ }^{21}$ LEVI-STRAUSS, Claude. Tristes Trópicos, São Paulo, Cia das Letras, 1998, p.88.

22 LEVI-STRAUSS, Claude. Tristes Trópicos, São Paulo, Cia das Letras, 1998, p.134.

${ }^{23}$ LEVI-STRAUSS, Claude. Tristes Trópicos, São Paulo, Cia das Letras, 1998, p. 126.

${ }^{24}$ LEVI-STRAUSS, Claude. Tristes Trópicos, São Paulo, Cia das Letras, 1998, p.89.
} 
os sintomas clínicos de uma agonia..., a vida num cantinho de nada...; Precisa-se de tão poucas coisas, aqui, para criar a humanidade...: pouco espaço, pouca comida, pouca alegria, poucos utensílios ou ferramentas..., populações jogadas e lançadas à voracidade do mercado mundial no contraste com a sua mente européia. Em seu espanto reflexivo, a as marcas da teoria estruturalista ainda em gestação mapeiam a estética de um urbano universal: Podíamos escrutar as cidades como botânico as plantas, reconhecendo pelo nome, pelo aspecto e pela estrutura de cada uma sua filiação a esta ou àquela família de um reino acrescentado pelo homem à natureza: o reino urbano ${ }^{25}$.

Se o tempo da narração, em Tristes Trópicos, é pura ondulação, uma poética da ação criadora como nos sugere Bachelard, o trabalho da tessitura da narrativa que LéviStrauss expõe, na performance de sua descrição etnográfica, à revelia do Cogito cartesiano do autor, espanta e interroga o seu próprio autor. Essa é, certamente, a riqueza da antropoética levistraussiana depositada nessa obra. Uma certa hermenêutica, mesmo que por vezes reduzida aos comentários moralistas do autor sobre a vida nos Trópicos - ainda que desejássemos tratar esses pobres coitados como iguais, eles protestariam contra a injustiça: suplica que os esmaguemos com nossa soberbia, conjuram-nos a isto... ${ }^{26}$, é aqui entregue à historicidade do questionamento de um pensamento que ao refletir, divaga - fiquei acabrunhado porque aquela noite me dera a ilusão de superar certas barreiras ${ }^{27}$, e do qual resulta a fragmentação da arte de narrar de Lévi-Strauss em Tristes Trópicos.

Em outro artigo ${ }^{28}$ havíamos apontado para o fato marcante de que, no corpo dos postulados do estruturalismo lévistraussiano, o estatuto do sujeito epistêmico do antropólogo não é confrontado com os paradoxos e as perplexidades da sua identidade pessoal no quadro da dimensão temporal tanto do si quanto da própria ação do seu pensamento sobre o mundo; o que se coloca é a "objetividade" através da certeza de que o Cogito, via neutralização da ipseidade, dá sobre a verdade de uma versão "subjetiva"

\footnotetext{
${ }^{25}$ LEVI-STRAUSS, Claude. Tristes Trópicos, São Paulo, Cia das Letras, 1998, p. 105.

${ }^{26}$ LEVI-STRAUSS, Claude. Tristes Trópicos, São Paulo, Cia das Letras, 1998, p.128.

${ }^{27}$ LEVI-STRAUSS, Claude. Tristes Trópicos, São Paulo, Cia das Letras, 1998, p. 131.

28 ECKERT, Cornelia e ROCHA, Ana Luiza Carvalho da. "A interioridade da experiência temporal do antropólogo como condição da produção etnográfica". In: Revista de Antropologia. Volume 41, número 2, 1998. São Paulo, Faculdade de Filosofia, Letras e Ciências Humanas, Universidade de São Paulo. P. 107 à 135.
} 
de regras inconscientes e universais da cultura humana, suas "estruturas permanentes"29.

Em Tristes Trópicos a exceção confirma a regra. Essa obra, pelas suas contradições, de idas e vindas, diferente das demais para ser compreendida em toda a sua honestidade e riqueza, não pode prescindir da figura do leitor e das suas experiências projetadas na própria voz do etnógrafo, num confronto constante de identidades e de alteridades recobertas na escrita do seu autor. Isso porque, no estilo da narrativa etnográfica adotada em Tristes Trópicos, é a construção/desconstrução do simesmo do antropólogo que prepondera ao longo do trajeto de descoberta do outro. Isto é, o Estranho e o Estrangeiro como parte do desvendamento da própria consciência ocidental, postos no confronto de seus múltiplos planos e espessuras: o contraste entre a paisagem da Velha Europa e o Novo Mundo, entre a Ásia meridional e a América tropical, submetido ao olhar do antropólogo, sugerindo ao leitor o mesmo lugar atópico vivido pelo autor da obra.

A tensão da obra, como nos romances de aventura, se consolida no constante embate do etnólogo com suas tradições e paradigmas, embate fundador da própria antropologia, agora projetado na descoberta do Novo pelo Velho Mundo. O autor consolida os vôos de seu pensamento, problematizando tempos e espaços relacionais, e tecendo os meandros de alteridades e de identidades, ainda que impregnado por uma visão eurocêntrica pautada no mito da História e do Progresso (de um tempo que se quer linear e contínuo), chegando, por vezes a reconhecer, no confronto com o "mundo perdido" das populações indígenas do Brasil central, que a base de nossas especulações é tão precária, que o menor reconhecimento no terreno coloca o pesquisador num estado instável em que ele se sente dividido entre resignação mais humilde e as loucas ambições... ${ }^{30}$.

Em Tristes Trópicos, a identidade do antropólogo desponta como um conceito relacional, atópico, sem que o autor, entretanto, preocupe-se em lhe dar um tratamento conceitual e teórico; o desvelamento do contexto semântico de sua obra é tarefa do leitor aguçado. Para interpretar as próprias palavras de C. Lévi-Strauss sobre a tristeza dos Trópicos, há que se lembrar de suas obras posteriores, pois para esse etnólogo toda identidade é uma ilusão, uma ilusão totêmica, cuja natureza deve ser estudada. É um conjunto de classificações, recorrentes, um mosaico de afirmações e negações, um

\footnotetext{
29 LÉVI-STRAUSS "no que é seguido por Dumont que, à semelhança de Mauss, agrega a dimensão do inconsciente aos 'elementos de base da ideologia'", cf. CARDOSO DE OLIVEIRA, R. Sobre o pensamento antropológico. Brasília, Tempo Brasileiro, 1988. p. 45.

${ }^{30}$ LEVI-STRAUSS, Claude. Tristes Trópicos, São Paulo, Cia das Letras, 1998. p.184.
} 
sistema de categorias que se entrelaçam numa geometria arbitrária. Nas palavras de outro antropólogo, a identidade deixa se apreender, ainda sob os Trópicos, através de um discurso, um grito, um canto alegre ou triste que nos permite o autoconsolo, a autoexaltação, ou como é muito comum na experiência brasileira, o autoflagelo ${ }^{31}$.

No entanto, a identidade desvendada na narrativa etnográfica sobre a vida humana que se consolida nos Tristes Trópicos é, principalmente, a figura do antropólogo e dos seus conceitos e teorias geradas no corpo de um eurocentrismo e que se revelam, até certo ponto, inoperantes para desvendar e compreender outros mundos. Um pensamento eurocêntrico - que o Ocidente recue às fontes de sua dilaceração ${ }^{32}$ que o próprio autor da obra corajosamente não nega, nem denega e que, por isso mesmo, mais tarde, permanecerá como fonte de reflexão até o aparecimento do seu já clássico estudo sobre o Pensamento Selvagem, onde, enfim, explicita os princípios que regem a ciência do concreto, uma resposta possível à experiência de sua viagem interior alucinada sob os meandros da mente européia sob os efeitos da paisagem tropical.

Em Tristes Trópicos, a perplexidade do autor se desvenda na sua constatação, nem sempre tranqüila, de que o pensamento antropológico genuíno é aquele que supera a oposição superior/inferior na construção do diálogo cultural - o que nos lembra suas sábias palavras a respeito do mito da identidade como insularidade, quando o etnólogo não percebe, no interior da prática antropológica, regularidades ou causalidades universais que lhe impõem a explicitação de seus julgamentos ético-morais ${ }^{33}$ e se pergunta, gerando no interior da indagação sua própria resposta: $\mathrm{Na}$ verdade, que mais aprendi com os mestres que escutei, com os filósofos que li, com as sociedades que visitei e com essa própria ciência da qual o Ocidente se orgulha, senão fragmentos de lições que, unidos uns aos outros, reconstituem a meditação do Sábio ao pé da arvore? $?^{34}$

A relação tensional e conflitual entre os dois mundos - o Velho e o Novo, a Ásia meridional e a América tropical, o Brasil central e o Brasil litorâneo -, na obra Tristes Trópicos, se afirma, portanto, como parte da tensão vivida por seu autor entre o universal e o relativo, conforme reconhece um de seus críticos ${ }^{35}$. Nas palavras do

\footnotetext{
${ }^{31}$ DA MATTA, Roberto. Explorações. p. 18.

${ }^{32}$ LEVI-STRAUSS, Claude. Tristes Trópicos, São Paulo, Cia das Letras, 1998, p.387.

${ }^{33}$ Cf. LEVI-STRAUSS, Claude. Actes du Séminaire "L'Identité". Paris, Quadrige/PUF, 1983. (1e édition: Grasset et Fasquelle, 1977). p. 330 a 332.

${ }^{34}$ LEVI-STRAUSS, Claude. Tristes Trópicos, São Paulo, Cia das Letras, 1998, p.389.

35 Segundo Geertz, "mediante o conhecimento de outras sociedades, podemos distanciar-nos da nossa própria e construir sobre a base de um ideal situado além do espaço e do tempo, uma ordem social
} 
autor, antes de sua chegada à baía da Guanabara: O que me cerca por todos os lados $e$ me esmaga não é a diversidade inesgotável das coisas e dos seres, mas uma só e formidável entidade: o Novo Mundo ${ }^{36}$.

A chave-mestra, portanto, do estilo narrativo de Lévi-Strauss, nessa obra, é a idéia do deslocamento, pela forma tensional do escritor-autor estranhar-se na tentativa de encontro à lógica do outro e familiarizar-se com o Estranho, onde proliferam reflexões diversas no sentido de atingir certas formas universais do pensamento e da moralidade, apregoando a universalidade da expressão da natureza humana. Nesse sentido, Lévi-Strauss, já nas páginas finais de Tristes Trópicos, comenta: Nenhuma sociedade é perfeita. Por natureza, todas comportam uma impureza incompatível com as normas em proclamam, e que se traduz de modo concreto numa certa dose de injustiça, de insensibilidade, de crueldade. Como avaliar essa dose? A resposta a este dilema lhe vem clara e imediatamente: A pesquisa etnográfica consegue, pois com ela, descobre-se então que nenhuma sociedade é fundamentalmente boa; mas nenhuma é inteiramente má. ${ }^{37}$

Essa é uma das lições, para além do que o próprio autor diria, é a grande lição apreendida com a leitura de Tristes Trópicos. Como sugere Geertz ${ }^{38}$, essa obra produzida pelo pensamento levistraussiano é, em determinados momentos da sua escritura, um registro do encontro entre uma mentalidade simbolista (a francesa) e outras mentalidades igualmente simbolistas (bororo, caduveo, nambikwara) no seu objetivo de penetrar totalmente sua coerência interna com a finalidade de achar nessas uma réplica do que constitui a mais fundamental forma de pensar. Ou ainda, nas palavras do autor: Em que ordem descrever essas impressões profundas e confusas que assaltam o recém-chegado a uma aldeia indígena cuja civilização permaneceu relativamente intacta?,(...) nessa meada de mil cores, que fio se deve seguir primeiro e tentar desembaraçar? ${ }^{39}$

São os múltiplos deslocamentos, do mundo eu ao mundo de si, até atingir a ipseidade, e do mundo do eu ao mundo exterior, na viagem que realiza entre o Velho Mundo e Novo Mundo, que permitem à Lévi-Strauss reordenar, sob a forma complexa, na sua obra Tristes Trópicos, as camadas diversas de tempo significantes no presente da

racional, em que o homem possa viver". GEERTZ, Clifford. El antropologo como autor. Barcelona, Paidos Studio, 1989. p. 48 e 49.

${ }^{36}$ LEVI-STRAUSS, Claude. Tristes Trópicos, São Paulo, Cia das Letras, 1998, p.76.

${ }^{37}$ LEVI-STRAUSS, Claude. Tristes Trópicos, São Paulo, Cia das Letras, 1998, p.189.

38 GEERTZ, Clifford. El antropologo como autor. Barcelona, Paidos Studio, 1989. p. 53.

${ }^{39}$ LEVI-STRAUSS, Claude. Tristes Trópicos, São Paulo, Cia das Letras, 1998. p. 202. 
escrita, numa série de imagens encadeadas da sua vida pensada, vivida, sonhada, como bem o exemplifica o "estado de graça" que o "espírito etnográfico" lhe provoca sob os efeitos do pôr-do-sol à medida que o descreve. ${ }^{40}$

Nessas imagens em que metaforicamente fala de partir e chegar, de começar e terminar, de viver e morrer, é o crepúsculo que ritma um ciclo de vida, um eterno retorno do começo e fim, que minituariza a noção de estrutura. Isso porque, em geral, concebemos as viagens como um deslocamento no espaço. É pouco. Uma viagem inscreve-se simultaneamente no espaço, no tempo e na hierarquia social. Cada impressão é definível se a relacionarmos de modo solidário com esses três eixos e, como o espaço possui sozinho três dimensões, precisaríamos de pelo menos cinco para fazermos da viagem uma representação adequada ${ }^{41}$. Ao deixar-se pensar através da imagem material do deslocamento, finalmente, abandona o pensamento etnográfico ao seu próprio devaneio, traduzindo tal estado introspectivo as múltiplas negociações afetivas, teóricas e práticas que realizou para finalmente experimentar a aventura de construir-se como etnógrafo sob os Trópicos. Como admitirá mais tarde, em seu retorno ao velho continente europeu: Onde melhor do que nesse sítio, que lhe apresenta seu microcosmo, o homem do Velho Mundo, reatando com sua história, poderia se interrogar" 42 .

A imaginação criadora do autor, para além da consciência de que ele pensa ter a posse, não passa despercebida ao leitor mais atento. Nela desvendam-se as suas estruturas de pensamento, captadas como sistemas de relações abstratas, representações que atualizam as estéticas das imagens individuais e coletivas sobre a existência humana, mas que, para se imporem, precisam negociar com a construção de sentido - as oposições de classes na forma de luta e tensão - que quer atribuir ao mundo das relações humanas sob os Trópicos - a ausência de "bons tempos" presentes à súplica, a esmola, as condições subumanas e desumanas reconciliadas com a gentileza dos olhares e sorrisos: (...) aqui o termo tensão não tem sentido. (...) e essa ausência de 'bons tempos' (...) deixa-nos diante de uma única convicção: todas essas pessoas com quem cruzamos na rua estão se perdendo. Para segurá- las por um instante ladeira abaixo, será que bastaria nos despojarmos? ${ }^{43}$

Do intervalo entre a viagem, o trabalho de campo marcado "por privações e

\footnotetext{
40 LEVI-STRAUSS, Claude. Tristes Trópicos, São Paulo, Cia das Letras, 1998. p 55.

${ }^{41}$ LEVI-STRAUSS, Claude. Tristes Trópicos, São Paulo, Cia das Letras, 1998, p.81.

${ }^{42}$ LEVI-STRAUSS, Claude. Tristes Trópicos, São Paulo, Cia das Letras, 1998, p 375.

${ }^{43}$ LEVI-STRAUSS, Claude Tristes Trópicos, São Paulo, Cia das Letras, 1998. p.129.
} 
lassidão fastidiosa" e a escrita etnográfica passaram-se 15 anos. Mas a possibilidade de remontar o tempo e retraçar a narrativa da viagem aos Trópicos seduz a ponto de o próprio autor refletir sobre sua transformação de filósofo a especialista em savoir-faires, explicitando na escrita dessa obra o que maravilhosamente elucidou na introdução à obra de Marcel Mauss ${ }^{44}$. Em Tristes Trópicos, Lévi-Strauss é confrontado ao acontecimento inter-subjetivo em que o cientista social torna-se, ele próprio, objeto de sua própria investigação ${ }^{45}$. Em suas palavras, ele comenta: No entanto, essa aventura iniciada no entusiasmo deixava-me uma impressão de vazio. Eu quisera ir até o ponto extremo da selvageria; não devia estar plenamente satisfeito entre aqueles graciosos indígenas que ninguém vira antes de mim, que talvez ninguém veria depois? ${ }^{46}$

Sabemos que em suas obras clássicas, C. Lévi Strauss não recupera essa dimensão hermenêutica da prática antropológica, tampouco constrói sua escritas etnográficas com base num estilo dialógico. Segundo inúmeros críticos do pensamento levistraussino, em sua hermenêutica redutora, o sujeito cognoscente do antropólogo nega a voz ao outro ao superpor as indagações e os dramas vividos por ele às suas próprias experiências temporais. Comentando sobre a ausência dos padrões da civilização ocidental na forma como se expressam as relações humanas na Ásia do sul, a arrogância da mente européia que habita a pessoa do etnólogo, inúmeras vezes, silencia a voz do outro, num tom implacável: Resta apenas uma sociedade na qual os que não são capazes de nada sobrevivem esperando tudo (que sonho tão oriental os gênios das Mil e uma noites) e na qual os que exigem tudo não oferecem nada ${ }^{47}$.

Não é por acaso, portanto, que ao revisitar sua experiência dos tempos vividos nos Trópicos e ao iniciar e finalizar a escrita de suas memórias, contrariando seu propósito de compreender a América mais do que aprofundar o estudo da natureza humana, é da morte que esse autor fala, talvez não da sua própria morte, mas da morte do outro, esvaziado de suas lembranças e tradições pela Europa faustiana e que lhe remete à ausência de futuro da civilização ocidental da qual faz parte. Ao final de Tristes Trópicos, o autor inicia um percurso alucinante de indagações sobre o seu lugar como etnógrafo num mundo cada vez mais ocidentalizado:(...) de que serve agir, se o pensamento que guia a ação conduz à descoberta da ausência de sentido? Mas essa

\footnotetext{
${ }^{44}$ LEVI-STRAUSS, Claude. "Introdução". In: MAUSS, Marcel. Sociologia e Antropologia. São Paulo, EPU, EDUSP, 1974.

45 O capítulo 31, intitulado Robinson, explicita esse movimento de ver-se como instrumento de observação. LEVI- STRAUSS, Claude. Tristes Trópicos, São Paulo, Cia das Letras, 1998.

${ }^{46}$ LEVI-STRAUSS, Claude. Tristes Trópicos, São Paulo, Cia das Letras, 1998. p.189.

${ }^{47}$ LEVI-STRAUSS, Claude. Tristes Trópicos, São Paulo, Cia das Letras, 1998, p.129.
} 
descoberta não é imediatamente acessível: tenho que pensá-la e não posso pensá-la de uma só feita. Logo após conclui, ao inverso do que inicialmente previa o curso do seu pensamento: "Como a pedra que bate numa onda e encrespa sua superfície ao atravessá-la, para atingir o fundo é preciso, primeiro que eu me jogue na água" ${ }^{48}$. No decurso desse pensamento de expiação, a constatação trágica: Devo dedicar-me aos homens assim como devo dedicar-me ao conhecimento.

Isso porque, lá onde Lévi-Strauss denuncia a ameaça irreversível do desaparecimento de culturas tradicionais do Brasil central, por exemplo, anuncia-se sua intolerância a civilização urbana sob os Trópicos como forma indireta de autoflagelo da mente européia culposa do próprio processo civilizatório que desencadeou sobre outras culturas, desde a Modernidade. Nas palavras do autor: (...) para nós, europeus e apegados à terra, a aventura ao coração do Novo Mundo significa antes de mais nada que ele não foi o nosso, que carregamos o crime de sua destruição e que, em seguida, não haverá outro igual: saibamos ao menos, reduzidos a nós mesmos por essa confrontação, expressá-la nos termos primeiros(... $)^{49}$. Polaridades opostas, Velho Mundo/Novo Mundo, que o pensamento alegórico lévistraussiano alude como estruturas, nos termos de seus estudos sobre a América indígena e seus ancestrais, mas que, do ponto de vista da civilização urbana sob os Trópicos, não chegam a sua expressão antagonista mais pura, residindo nessa faceta o destino trágico e, por isso mesmo triste, segundo expressão do autor, da vida humana sob os Trópicos.

Mas se, hoje, pode-se dizer que Tristes Trópicos é uma obra que não responde às expectativas de uma antropologia do mundo urbano contemporâneo, sua escritura significou, sem dúvida, a presença de uma descontinuidade não só no corpo das obras deste autor, mas também na própria trajetória da matriz disciplinar da Antropologia. Com Lévi-Strauss, após a publicação de Tristes Trópicos, não somente os povos "primitivos", "diferentes" ou "exóticos" tornaram-se objetos privilegiados dos estudos antropológicos, mas provocaram uma reflexão diferida das diferenças que o antropólogo vivencia em sua própria sociedade. Segundo comenta o autor, inspirado pelo projeto intelectual iluminista de J.J. Rousseau: O estudo desses selvagens traz outra coisa além da revelação de um estado natural utópico, ou a descoberta da sociedade perfeita no coração das florestas; ajuda-nos a construir um modelo teórico da sociedade humana, que não corresponde a nenhuma realidade observável, mas graças ao qual o Ocidente,

\footnotetext{
${ }^{48}$ LEVI-STRAUSS, Claude. Tristes Trópicos, São Paulo, Cia das Letras, 1998, p. 390.

${ }^{49}$ LEVI-STRAUSS, Claude. Tristes Trópicos, São Paulo, Cia das Letras, 1998, p. 372.
} 
recuando até as fontes de sua dilaceração, retomaria a oportunidade de reunir o mundo temporal e o mundo espiritual e permanecer mulher.

Integrados numa totalidade maior, "nós" e "eles", tornamo-nos objetos de investigação; o movimento/deslocamento, anunciado em Tristes Trópicos, transformou a etnologia em uma disciplina moderna, na perspectiva do que Lévi-Strauss explicita, nos anos 70, quando alerta para os perigos de o antropólogo, no mundo contemporâneo, anular ou nuançar o ponto cego da Diferença no interior da conformação da Identidade do próprio do etnógrafo, o que significaria o perigo de esse incorrer num etnocentrismo por anexação ${ }^{50}$.

Nessa perspectiva, a honestidade a qualquer preço que impregna a escritura etnográfica dos Tristes Trópicos situa essa obra do pensamento levistraussiano como transgressora à crise que prendia a Antropologia aos cânones de um objeto de estudo específico e historicamente congelado na qualidade de povos exóticos tal qual inaugurados pelos postulados evolucionistas. Se o Ocidente produziu etnógrafos avalia o autor em Tristes Trópicos, certamente, foi porque um remorso muito forte devia atormentá-lo, obrigando-o a confrontar sua imagem com a de sociedade diferentes na esperança de que refletissem as mesmas taras ou o ajudassem a explicar de que maneira as suas se desenvolveram no seu seio, e complementando, mais adiante: (...) o etnógrafo pode se desinteressar de sua civilização e pouco se envolver com seus erros na medida em que sua existência mesma é incompreensível, a não ser como uma tentativa de redimir: ele é o símbolos da expiração. Finalmente alerta, (...) contudo, essa condenação de nós mesmos, por nós mesmos infligida, não implica atribuirmos um prêmio de excelência a esta ou aquela sociedade presente ou passada, localizada num ponto determinado do tempo e do espaço. Aí residiria verdadeiramente a injustiça(...): nós a condenaríamos pela mesma razão que condenamos esta a que pertencemos. A subversão promovida pela publicação desta obra, nos anos 50, no que tange às falácias da falsa consciência do pensamento antropológico, e inclusive nos termos das produções futuras de Lévi-Strauss, alargou, portanto, a lei moral que se impõe doravante indistintamente a todos nós, cientistas sociais: o direito moral do homem como ser vivo é relacional ao direito da existência de todas as espécies vivas.

Alargando a liberdade à ordem geral do mundo, ao refletir sobre a fome, o lixo,

\footnotetext{
50 Cf. LEVI-STRAUSS, Claude. Actes du Séminaire "L'Identité". Paris, Quadrige/PUF, 1983. (1e édition: Grasset et Fasquelle, 1977). p. 330 a 332.
} 
as imundícies, a miséria, a desordem, as secreções, as purulências, o ajuntamento, a promiscuidade e as ruínas da civilização urbana sob os Trópicos e sua ação devastadora para as regiões mais distantes do planeta terra, Lévi-Strauss, na expressão magistral de contradição de uma lúcida "mente européia", propõe o olhar relacional sobre si e sobre o outro, numa (auto)crítica ao ato do mundo ocidental de destruição das culturas, em meio à perplexidade da presença da Diferença: Era como se os especialistas do outro lado do Atlântico procurassem impor à América indígena essa ausência de profundidade que caracteriza a história contemporânea do Novo Mundo. Perplexidade face à Diferença, vale ressaltar, que não obteve, por parte do etnólogo, a mesma indulgência na forma como ele observa a instalação da civilização urbana no Novo Mundo por ele empregada em seus comentários sobre as populações indígenas do Brasil central.

Entretanto, de uma forma ou de outra, a divulgação dessa obra de Lévi-Strauss significou a expansão do objeto da Antropologia, situando seu moderno objetivo na reflexão sobre as diferenças culturais, sempre renovadas nas maneiras de ser e de agir dos homens, embora Lévi Strauss não classifique Tristes Trópicos como um livro científico, mas antes uma reconstituição honesta de suas impressões chegando ao Novo Mundo.

Rastrear as estratégias de escrita em Tristes Trópicos pode remeter ao leitor simplesmente à superfície da arte da narrativa etnográfica tecida a partir dos jogos relacionais através dos quais Lévi-Strauss constrói a própria impressão e o espanto do antropólogo no sentido de sua intenção inicial: explicar a totalidade que abarca a vida humana através de sua percepção entre o Velho e Novo mundo, entre ciclo longo (Europeu) e ciclo rápido (América, Ásia). Entretanto, adentrar-se às profundezas do pensamento levistraussiano expresso nessa obra exigiria mais de seu leitor, isto é, significaria sua disposição em rastrear a estética do "tempocentrismo histórico" que preside a configuração da intriga engendrada pela narrativa etnográfica do autor ${ }^{51}$.

Por inúmeras razões, pode-se argumentar aqui que é o gênero da narrativa etnográfica desse "autor-escritor" ${ }^{32}$ que permitiu um projeto de mudança e de atualização da disciplina, isto é, justamente a modalidade de intriga que sustenta o relato

\footnotetext{
51 "Um novo continente que ele priva de um tempo-história. Uma estranha forma de etnocentrismo ou de tempocentrismo - num antropólogo", sugere Canevacci In CANEVACCI, Massimo. "São Paulo e Nova York 'dentro' de Lévi-Strauss. A cidade polifônica. Studio Nobel. 1993. p. 85.

${ }^{52}$ Cf. GEERTZ, Clifford. El antropologo como autor. Barcelona, Paidos Studio,1989, nomeia C. LeviStrauss nesta obra.
} 
etnográfico levistraussiano em Tristes Trópicos, onde a narrativa etnográfica que esboça os traços da experiência temporal vivida pelo autor do texto ultrapassa a própria intenção inicial do autor - "compreender a América" -, progressivamente transformado em personagem de uma história singular; o orgulho intelectual destituído de função quando o autor descobre que entre um nós e um nada, o seu eu não encontra lugar de afirmação.

Ao término da leitura de Tristes Trópicos fica, portanto, no leitor, uma sensação incômoda: o Novo Mundo não é uma extensão pura e simples do Velho Mundo, ele possui sua lógica interna que o singulariza, e é diante dessa constatação banal que o pensamento eurocêntrico do autor se fragiliza. Diferentemente da "ausência de tempo" apontada por Lévi- Strauss, sob os Trópicos o que interpela a "mente européia, nessa região do hemisfério, o Tempo que se expressa em sua feição mais tênue, sem aderir ao mito do Progresso histórico; disperso e lacunar só pode ser mensurado pela vibração acidental da sua matéria em ritmos agitados, cuja regularidade só pode ser observada por Lévi-Strauss quando esse dirigia sua atenção à regularidade da freqüência dos ritmos de suas manifestações delicadas ${ }^{53}$.

Nesse sentido, contrariando a arrogância do pensamento eurocêntrico, no Novo Mundo, o tempo existe ${ }^{54}$, com toda a força do termo, e em sua forma vibratória, para além de um princípio de uniformidade a ele atribuído pela Europa das Vitórias, ele surpreende a tal ponto o etnólogo que ele próprio admite: sob os Trópicos trata-se antes de reconhecer uma "entropologia" e nem tanto uma antropologia 55 .

Em Tristes Trópicos, o pensamento estruturalista é constantemente desafiado e é justamente pelo caráter trágico de um pensamento levistraussiano que pretende acessar, por isomorfismos diversos, com base apenas nas propriedades formais do pensamento do homem da civilização, a agitação intestina ${ }^{56}$ da matéria sobre a qual se expressa a vida humana sob os Trópicos. A tragicidade de seu percurso ("viagem mental"), da trama que o configura, reside, precisamente, no fato de que tão-somente a dissolução, por parte desse autor-personagem, de seus esquemas estáveis e regulares de pensar e agir no mundo se mostra como única forma viável de mergulhar na descontinuidade/instabilidade desta experiência temporal humana: Uns conhecem pela

\footnotetext{
${ }^{53}$ A propósito, seguem-se aqui idéias desenvolvidas por A. L. C. da Rocha, uma das autores deste artigo, em sua Tese de Doutorado "Le sanctuaire du dèsordre, l'art de vivre des tendres barbares sous les Tristes Tropiques, esthétique urbaine et mémoire collective au sud du Brésil”, Paris V, Sorbonne, 1994.

${ }^{54}$ BACHELARD, Gaston. La dialéctique de la durée. PUF, 1989.

${ }^{55}$ LEVI-STRAUSS, Claude. Tristes Trópicos, São Paulo, Cia das Letras, 1998, p.390.

${ }^{56}$ Expressão cunhada por Bachelard, em sua obra La terre et les rêveries de la volonté.
} 
ação, outros se realizam pensando, mas a contradição aparente, que decorre da coexistência entre ele, se resolve na obrigação que temos de atribuir um sentido aos mais próximos e recusá-los aos demais, enquanto a verdade está numa dilatação progressiva do sentido, mas em ordem inversa e levada até a explosão ${ }^{57}$.

$\mathrm{Na}$ antropoética que marca o traço característico dessa obra, o etnógrafo não é somente autor-escritor, mas personagem da trama que narra; o intelectual francês, na Ásia meridional ou na América tropical, torna-se, assim, progressivamente personagem de sua própria história, assujeitado às aventuras de seu próprio pensar, até a fatalidade do reconhecimento, por acúmulos de experiências dissonantes, da perda dos significados de sua própria ordem cultural, esfacelada face à presença do homem da tradição no coração das próprias distorções que o próprio Ocidente moderno implantou sobre extensões de terra distantes.

Nesses termos, pode-se afirmar que não há discordância entre o que aqui se esta referindo e os comentários que propõe C. Geertz ${ }^{58}$ ao anunciar que Lévi Strauss não quer que o leitor se espelhe no texto, quer que se espelhe nele e, assim procedendo, segundo a via interpretativista, tornar-se-ia muito difícil olhar através dele. Sem dúvida, em Tristes Trópicos o outro não tem voz, sangue e ossos, sendo desafiado a ir além da estranheza de Lévi-Strauss a respeito das populações que ali habitam.

No entanto, mesmo não se tendo a remota possibilidade de conhecer esse Estranho, suas histórias, sonhos e cotidiano, que se prestam apenas à formação de oposições, inversões e isomorfismos no que tange ao paradigma da "mente européia", possibilidade de o Estranho elevar-se à condição de humanidade, é a memória involuntária, a estetização das lembranças do etnólogo, contaminando sua prática descritiva que desponta como tema central da tessitura da intriga de Tristes Trópicos ${ }^{59}$. Isso porque, como a própria perspectiva hermenêutica nos ensina, Tristes Trópicos retrata as impressões de viagens de C. Lévi-Strauss e não há razões para que se atribua a tais impressões algo mais do que elas puderem ou conseguirem transmitir ao leitor, a menos que a severidade do olhar atribuído a essa obra não consiga sequer capturar o trágico do pensar humano que acompanha o ofício do antropólogo, estruturalista ou não. Com a publicação de Tristes Trópicos, nós, antropólogos dos Tristes Trópicos,

\footnotetext{
${ }^{57}$ LEVI-STRAUSS, Claude. Tristes Trópicos, São Paulo, Cia das Letras, 1998. p.390.

${ }^{58}$ GEERTZ, Clifford. El antropologo como autor. Barcelona, Paidos Studio, 1989, p. 58.

59 GEERTZ, Clifford. El antropologo como autor. Barcelona, Paidos Studio, 1989 Geertz, 1989, p.42, explicita que em Tristes Trópicos a escritura etnográfica segue a mais fina tradição literária estabelecida por Baudelaire, Mallarmé, Rimbaud e Proust, poetas da memória involuntária.
} 
lucramos, pois ela nos permite reconhecer o lugar do mundo a partir do qual as palavras desse autor foram proferidas tanto quanto o universo daqueles a quem se destina.

Seguindo o paradigma hologramático ${ }^{60}$, para nós, antropólogos dedicados a decifrar o teatro da vida urbana sob os Trópicos, o que fica de perene nessa obra é que podemos recuperar outras facetas da vida intelectual desse antropólogo estrangeiro vivendo em terras estranhas, o que nos auxilia a compreender a perspectiva eurocêntrica de se pensar a vida humana em outras regiões do planeta e avaliar o fantasma do colonialismo intelectual que assombra, vez por outra, o destino do pensamento social no Brasil e que esse autor, ironicamente, denominou "apetite enciclopédico" como sendo a marca da criação científica local, fruto, segundo suas palavras, da combinação entre $a$ fortuna herdada, o charme inato e a matreirice adquirida, que tornavam a frequentação dos salões tão deliciosa e ao mesmo tempo tão decepcionante ${ }^{61}$.

Pode-se, indo-se além, ler Tristes Trópicos às avessas. Isto é, capturar na sua escritura e na trama que aí se desenrola, a revelação da árdua tarefa que muitos antropólogos franceses têm, até hoje, negligenciado, ou seja, o mergulho profundo nos tempos históricos internos de sua própria tradição cultural e nas reminiscências do processo de construção da identidade nacional francesa, fenômeno do qual decorre a insistência do pensamento levistraussiano, nessa obra, em construir a figura do outro na figura do árabe, do asiático ou do americano em vez do francês e do europeu.

Por essa via, conforme o paradigma hologramático, Tristes Trópicos revelar-nosia que se a parte está contida no todo, o todo pode ser capturado nas suas partes. Nesse sentido, há que se ler, hoje, Tristes Trópicos no sentido de descobrir a tristeza, não dos Trópicos, mas do pensamento moribundo de um Velho Mundo que agoniza e onde as promessas de um destino faustiano da época da Europa das Vitórias não se cumpriram. Isso nos remete aqui a lembrar as derradeiras palavras do autor que encerram Tristes Trópicos: E se é por esse nós que enfim opto, embora se reduza a uma aparência, é porque, a não ser que ele me destrua - ato que suprimiria as condições de opção -, só tenho uma escolha possível entre essa aparência e nada.

\footnotetext{
60 Cf. CANEVACCI, Massimo. "São Paulo e Nova York 'dentro' de Lévi-Strauss. In: A cidade polifônica. Studio Nobel. 1993, p. 81.

${ }^{61}$ LEVI-STRAUSS, Claude. Tristes Trópicos, São Paulo, Cia das Letras, 1998, p.96.
} 


\section{BIBLIOGRAFIA}

BACHELARD, Gaston. La terre et les rêveries de la volonté.

BACHELARD, Gaston. La dialéctique de la durée. PUF, 1989

CANEVACCI, Massimo. "São Paulo e Nova York 'dentro' de Lévi-Strauss. In: A cidade polifônica. Studio Nobel. 1993.

CARDOSO DE OLIVEIRA, R. Sobre o pensamento antropológico. Brasília, Tempo Brasileiro, 1988.

DA MATTA, Roberto. Explorações.

ECKERT, Cornelia e ROCHA, Ana Luiza Carvalho da. "A interioridade da experiência temporal do antropólogo como condição da produção etnográfica". In: Revista de Antropologia. Volume 41, número 2, 1998. São Paulo, Faculdade de Filosofia, Letras e Ciências Humanas, Universidade de São Paulo. P. 107 à 135.

GEERTZ, Clifford. El antropologo como autor. Barcelona, Paidos Studio, 1989.

LEVI-STRAUSS, Claude. Tristes Trópicos, São Paulo, Cia das Letras, 1998.

LEVI-STRAUSS, Claude. Tristes Tropiques. Paris, Plon 1955.

LEVI-STRAUSS, Claude. "Introdução". In: MAUSS, Marcel. Sociologia e Antropologia. São Paulo, EPU, EDUSP, 1974.

LEVI-STRAUSS, Claude. Actes du Séminaire "L'Identité". Paris, Quadrige/PUF, 1983. (1e édition: Grasset et Fasquelle, 1977). p. 330 a 332.

LEVI-STRAUSS, Claude. Anthropologie structurale. Paris, Plon, 1958.

LEVI-STRAUSS, Claude. La pensée sauvage. Paris, Plon, 1962.

LEVI-STRAUSS, Claude. Le regard éloigné. Paris, Plon, 1983.

LEVI-STRAUSS, Claude. Les Structures Elémentaires de la Parenté. Paris, PUF, 1949. LEVI-STRAUSS, Claude. Mythologiques I, Le cru et le cuit, Paris, Plon, 1964. Mythologiques II, Du miel aux cendres, Paris, Plon, 1966, Mythologiques III, L'origine des manières de table. Paris, Plon, 1968, Mythologiques IV, L’homme nu. Paris, Plon, 1971

LEVI-STRAUSS, Claude. O pensamento selvagem. São Paulo, Companhia Editora Nacional, Editora da Universidade de São Paulo, 1970.

LEVI-STRAUSS, Claude. Tristes Trópicos. Lisboa, Edições 70, 1981.

MEUNIER Jacques. “Tropicales”, In: Magazine Litttéraires. Numero 223, DOSSIER Paris octobre 1985.

ROCHA, Ana Luiza Carvalho da, "Le sanctuaire du dèsordre, 1'art de vivre des tendres 
barbares sous les Tristes Tropiques, esthétique urbaine et mémoire collective au sud du Brésil", Thèse de Doctorat. Paris V, Sorbonne, 1994. 